\title{
Ketidaksesuaian Diet pada Pasien di ICU dengan Faktor - faktor yang Berhubungan dengannya
}

Khairuddin, Etisa Adi Murbawani

\section{Bagian Gizi, Fakultas Kedokteran,Universitas Diponegoro}

\section{ABTRAK}

Latar Belakang: Ketidaksesuaian dietyang ditentukan dengan diaet yang diterima pasien dapat terjadi pada pasien yang di rawat diunit perawatan intensif (ICU), tetapitidak ada penelitian yang mengamati perbedaan tersebut.

Tujuan: Untuk menganalisis beberapa faktor yang terkait dengan perbedaan antara diet yang ditentukan dengan diat yang diterimapasien, dan untukmenentukan faktor yang memiliki hubungan kuat dengan perbedaan tersebut.

Metode: Penelitian ini menggunakan metode cross sectional dengan mengamati perbedaan antara diet yang ditentukan dalam rekam medis dan diet yang diterima oleh pasien berdasarkan daftar makanan dari pantry ICY. Analisis data dari faktor yang diamati menggunakan uji chi-square diikuti engan uji regresi logistik

Hasil:Perbedaanantara diet yang ditentukan dengan diet yang diterima pasien dalam penelitian ini adalah 70 dari $249(28,1 \%)$ koresponden. Hasil uji chi-square, nilai p dan koefisien kontingensi adalah: waktu penulisan resep $(\chi 2=1,387 ; \mathrm{p}=0,239)$; hari penulisan resep $(\chi 2=0,508 ; \mathrm{p}=0,476)$; perubahan dalam diet dalam hari yang sama $(\chi 2$ $=13,972 ; \mathrm{p}<0,001, \mathrm{C}=0,231)$; kombinasi jenis diet $(\chi 2=13,761 ; \mathrm{p}<0,001, \mathrm{C}=0,229)$. Nilai $\mathrm{p}$ dan OR dari uji regresi logistik adalah: perubahan diet dalam hari yang sama (p $<0,001, \mathrm{OR}=8,433)$; kombinasi jenis diet ( $\mathrm{p}<0,001, \mathrm{OR}=5,013)$.

Kesimpulan: Ketidaksesuain diet pasien di ICU dengan perubahan diet dalam hari yang sama dan adanya kombinasi jenis diet yang ditentukan. Faktor yang paling berkaitan dengan perubahan pola makan dalam hari yang sama.

Kata kunci:pasien, ICU, Diet,Ketidaksesuain 


\section{PENDAHULUAN}

Malnutrisi merupakan hal yang umum terjadi pada pasien-pasien yang dirawat di intensive care unit (ICU). Pasien sakit kritis pada saat masuk ke ruang ICU mungkin sudah dalam keadaan malnutrisi atau berisiko malnutrisi, akan tetapi pasien yang masuk ICU dengan status gizi yang baik pun dapat berkembang dengan cepat menjadi malnutrisi akut. Penelitian yang dilakukan oleh Mannsdörfer et al mendapatkan bahwa dalam 3 hari pertama masuk ICU, sebanyak $66 \%$ pasien berisiko malnutrisi, meskipun sebagian besar pasien tersebut mempunyai berat badan normal atau bahkan berlebih. ${ }^{1}$ Malnutrisi pada pasien sakit kritis berhubungan dengan fungsi sistem imun yang menurun, gangguan ventilasi, dan kelemahan otot-otot pernapasan sehingga memperpanjang ketergantungan pada ventilator, dan meningkatkan morbiditas dan mortalitas terkait infeksi. ${ }^{2}$ Tata laksana malnutrisi yang efektif diperlukan untuk mencegah atau meminimalkan dampak tersebut. Hal ini memerlukan kolaborasi yang kuat antara komponen-komponen yang berperan, yaitu perawat yang melakukan skrining gizi dan menjamin kepatuhan terhadap intervensi gizi, dokter gizi klinis yang melengkapi asesmen, diagnosis gizi dan membuat preskripsi gizi, serta dokter penanggung jawab pelayanan sebagai pemegang tanggung jawab dalam keseluruhan rencana pelayanan pasien. ${ }^{3}$

Beberapa penelitian telah melaporkan terjadinya ketidaksesuaian antara diet yang dipreskripsikan dengan diet yang diterima pasien di ICU. Jonghe et al melakukan studi prospektif pada pasien yang dirawat di ICU dan mendapatkan bahwa rata-rata pasien menerima asupan energi sebesar 71,2\% dari kebutuhan. ${ }^{4}$ Studi yang dilakukan oleh Heyland et al menunjukkan bahwa rata-rata pasien ICU hanya mendapatkan $61,2 \%$ energi dan $57,6 \%$ protein dari yang dipreskripsikan. Selain itu, sebanyak $74 \%$ pasien tidak memenuhi target asupan minimal sebesar $80 \%$ dari kebutuhan energi. ${ }^{5}$ Silva et al menunjukkan bahwa target asupan tercapai hanya pada $22 \%$ pasien. ${ }^{6}$ O’Meara et al dalam penelitiannya pada salah satu ICU di rumah sakit di Amerika Serikat menunjukkan bahwa pasien menerima asupan energi hanya sekitar $50 \%$ dari yang dipreksipsikan. ${ }^{7}$ Hasil ini juga didukung oleh penelitian dari Sudenis et al pada pasien luka bakar yang mendapatkan asupan energi berkisar antara $19 \%$ sampai 91\% dari yang dipreskripsikan. ${ }^{8}$ Penelitian oleh Kim et al pada pasien ICU di rumah sakit di Korea memberikan hasil sebanyak $62 \%$ pasien mendapatkan asupan energi yang kurang dan $56 \%$ pasien kurang asupan protein. ${ }^{9}$ Tatucu-Babet et al yang melakukan telaah sistematis literatur mendapatkan bahwa $38 \%$ pasien ICU menerima asupan energi $<90 \%$ dari kebutuhannya yang dihitung menggunakan indirect calorimetry. ${ }^{10}$

Berbagai faktor yang berpengaruh pada terjadinya ketidaksesuaian diet dalam tata laksana gizi pada pasien ICU telah diungkapkan oleh beberapa 
penelitian. ${ }^{4,11-16}$ Cahill et al mengemukakan beberapa hal utama yang menjadi barrier dalam pemberian diet pada pasien ICU adalah prioritas pemberian gizi masih terkalahkan oleh aspek perawatan lain, ketersediaan alat seperti feeding pump yang terbatas, tidak tersedianya formula enteral yang dibutuhkan, kurangnya petugas gizi terutama pada akhir pekan, serta keterlambatan dalam memulai pemberian gizi secara enteral. ${ }^{11}$ Hal lain yang sering menjadi kendala dalam pemberian makan secara enteral, khususnya pemberian enteral berkelanjutan (continuous enteral nutrition) adalah pelaksanaan berbagai prosedur baik diagnostik maupun klinis yang menyebabkan proses pemberian makan terhenti sementara. Penelitian oleh Ramakrishnan et al menunjukkan bahwa sekitar $74 \%$ pasien mengalami interupsi pada saat mendapatkan tata laksana gizi enteral akibat berbagai prosedur yang dilakukan. ${ }^{13}$

Studi literatur yang dilakukan oleh Kim et al memberikan gambaran komprehensif faktor-faktor yang menyebabkan pasien di ruang ICU mendapatkan asupan gizi yang kurang. Faktor-faktor ini tampaknya tidak berhubungan dengan keadaan pasien seperti umur dan jenis kelamin, status gizi, tingkat keparahan penyakit, maupun penggunaan ventilator mekanik. Pemberian gizi enteral yang terlambat, lambatnya peningkatan target asupan, serta preskripsi gizi yang kurang adekuat merupakan faktor-faktor yang ditengarai menyebabkan tidak adekuatnya asupan gizi pada pasien ICU. Namun demikian, faktor yang memberikan kontribusi paling besar adalah adanya interupsi pada saat pasien mendapatkan gizi enteral. Interupsi ini terutama disebabkan oleh prosedur diagnostik atau tindakan operasi, intoleransi gastrointestinal terhadap pemberian gizi enteral, salah posisi atau obstruksi pada feeding tube, maupun prosedur keperawatan rutin. ${ }^{12}$

Selain ketidaksesuaian jumlah energi, hal lain yang mungkin terjadi dalam penatalaksanaan gizi pada pasien di ICU adalah ketidaksesuaian antara diet yang dipreskripsikan dengan diet yang diterima pasien, akan tetapi sampai saat ini belum ada penelitian yang mengkaji masalah tersebut. Penelitian ini bertujuan untuk mengamati adanya ketidaksesuaian antara diet yang dipreskripsikan dengan diet yang diterima pasien di ruang ICU serta menganalisis faktor- faktor yang berhubungan dengan ketidaksesuaian tersebut. Hasil penelitian ini diharapkan dapat bermanfaat dalam pembuatan atau melakukan revisi terhadap kebijakan, pedoman dan standar tata laksana gizi pada pasien di ruang ICU.

\section{METODE}

Penelitian ini adalah penelitian observasional dengan menggunakan metode cross sectional. Pengamatan dilakukan pada diet yang dipreskripsikan pada pasien yang dirawat di ICU RSUP Dr Kariadi, dibandingkan dengan diet yang diterima pasien tersebut. Waktu penelitian adalah 30 hari yaitu pada tanggal 6 Nopember s/d 5 Desember 2017. 
Subyek penelitian adalah semua preskripsi diet untuk pasien yang dirawat di ICU RSUP Dr Kariadi selama periode waktu penelitian yang memenuhi kriteria inklusi. Pengambilan sampel penelitian dilakukan dengan cara total sampling berbasis waktu, semua preskripsi diet pada pasien ICU yang ditulis selama periode waktu penelitian yang memenuhi kriteria inklusi dimasukkan sebagai subyek penelitian. Kriteria inklusinya adalah: a) preskripsi diet yang ditulis oleh dokter spesialis gizi klinik atau oleh asistennya yang sudah diverifikasi oleh dokter spesialis gizi klinis; dan b) diet yang dipreskripsikan adalah diet secara oral atau enteral, baik sebagai tata laksana gizi tunggal maupun kombinasi dengan diet parenteral. Subyek akan dieksklusi jika tulisan preskripsi tidak dapat dibaca atau preskripsi tidak mencantumkan jenis dan/atau volume diet.

Pengumpulan data dilakukan setiap hari selama periode penelitian sampai periode waktu penelitian selesai. Semua data diambil dari rekam medis pasien dan catatan pemberian diet (food list) dari bagian pantry ruang ICU RSUP Dr Kariadi. Data yang dikumpulkan meliputi jumlah energi dan protein, jenis diet (cair I, cair II, lunak, tim, nasi, serta jenis formula enteral), jumlah takaran formula enteral, volume air yang digunakan untuk membuat formula enteral, frekuensi pemberian, serta hari, tanggal, dan jam penulisan preskripsi. Selanjutnya dibandingkan ketidaksesuaian data tersebut antara data diet yang dipreksripsikan secara tertulis di rekam medis pasien pada Lembar Catatan Terintegrasi (CM4) dan data diet yang diberikan kepada pasien berdasarkan daftar makanan pasien (food list) yang dibuat oleh bagian pantry ruang ICU RSUP Dr Kariadi.Diet dinyatakan tidak sesuai jika terdapat perbedaan minimal salah satu dari hal-hal tersebut antara diet yang dipreskripsikan dengan diet yang diterima pasien.

Variabel bebas dalam penelitian ini adalah waktu penulisan preskripsi diet, hari penulisan preskripsi, adanya perubahan diet dalam hari yang sama, dan adanya kombinasi jenis diet dalam preskrispi, sedangkan variabel tergantung adalah ketidaksesuaian diet. Semua variabel tersebut berskala nominal dan masing-masing dibagi ke dalam 2 kategori dikotomik. Waktu penulisan preskripsi dibagi ke dalam 2 kategori yaitu $<$ jam 10.00 WIB atau $\geq$ jam $10.00 \mathrm{WIB}$, hari penulisan preskripsi dibagi menjadi hari kerja atau akhir pekan, perubahan diet dalam hari yang sama dibagi menjadi ada perubahan atau tidak, sedangkan kombinasi jenis diet dibagi menjadi ada kombinasi atau tidak. Jenis diet disebut kombinasi jika diet yang diberikan berupa gabungan antara sonde/cair I dengan cair II/lunak, dan tidak kombinasi jika diet yang diberikan hanya berupa sonde/cair I.

Analisis data statistik deskriptif digunakan untuk menganalisis data kualitatif yang dinyatakan sebagai jumlah dan persentase. Terjadinya ketidaksesuaian antara diet yang dipreskripsikan dengan diet yang diterima pasien dinyatakan sebagai persentase jumlah diet yang tidak sesuai terhadap jumlah keseluruhan diet. 
Analisis chi-square digunakan untuk menilai hubungan antara masing-masing faktor yang dianalisis dengan ketidaksesuaian diet. Tingkat kekuatan hubungan antara faktor-faktor tersebut dengan ketidaksesuaian diet dinilai dengan menggunakan parameter nilai koefisien kontingensi. Selanjutnya dilakukan analisis regresi logistik untuk menilai faktor yang mempunyai hubungan paling kuat terhadap ketidaksesuaian diet.

\section{HASIL PENELITIAN}

Selama 30 hari periode penelitian, jumlah seluruh subyek penelitian adalah 249 preskripsi diet. Pengamatan yang dilakukan terhadap seluruh subyek penelitian menunjukkan bahwa preskripsi yang sesuai adalah sebanyak 179 $(71,9 \%)$ preskripsi, sedangkan yang tidak sesuai adalah sebanyak $70(28,1 \%)$ preskripsi.

Ketidaksesuaian diet tersebut dapat dikelompokkan ke dalam beberapa kategori yaitu perbedaan nama formula yang diberikan, nama formula yang diberikan sesuai akan tetapi jumlah takarannya berbeda, volume air yang digunakan untuk membuat formula tidak sesuai, perbedaan frekuensi pemberian, pasien yang TM (tidak makan/minum) diberikan diet dan sebaliknya pasien yang tidak TM tidak diberikan diet, serta ketidaksesuain jumlah energi yang diberikan. Frekuensi masing-masing ketidaksesuaian diet tersebut dapat dilihat pada tabel 1 .

Tabel 1.Jenis-jenis ketidaksesuaian preskripsi diet

\begin{tabular}{|c|c|c|}
\hline \multirow{3}{*}{ Kategori } & \multicolumn{2}{|c|}{ Total $(n=70)$} \\
\hline & \multirow[b]{2}{*}{$\mathbf{n}$} & \multirow[b]{2}{*}{$\%$} \\
\hline & & \\
\hline \multicolumn{3}{|l|}{ Ketidaksesuaian volume air yang digunakan untuk } \\
\hline membuat formula & 14 & 20,0 \\
\hline Ketidaksesuaian jumlah takaran formula & 13 & 18,6 \\
\hline Pasien yang seharusnya TM tetapi diberikan diet & 13 & 18,6 \\
\hline Ketidaksesuaian nama formula yang diberikan & 11 & 15,7 \\
\hline Jumlah energi tidak sesuai dengan yang dipreskripsikan & 8 & 11,4 \\
\hline Pasien yang tidak TM tetapi tidak diberikan diet & 7 & 10,0 \\
\hline Ketidaksesuaian frekuensi pemberian & 4 & 5,7 \\
\hline
\end{tabular}

Keterangan: $\mathrm{TM}=$ tidak makan/minum

Ketidaksesuaian volume air yang digunakan untuk membuat formula merupakan jenis ketidaksesuaian yang paling sering terjadi yaitu 20\% dari jumlah seluruh ketidaksesuaian yang ada, diikuti ketidaksesuaian jumlah takaran formula yang frekuensinya sama dengan frekuensi kejadian pasien yang seharusnya TM tetapi diberikan diet. Jenis ketidaksesuaian yang paling sedikit adalah ketidaksesuaian frekuensi pemberian yaitu hanya 4 kali atau 5,7\% dari seluruh jenis ketidaksesuaian. 
Hubungan antara masing-masing faktor yang dianalisis dengan ketidaksesuaian diet dianalisis dengan uji chi-square. Hasil uji chi-square terhadap variabel-variabel yang diamati serta nilai $p$ dan koefisien kontingensinya ditampilkan dalam Tabel 2. Hasil analisis multivariat dengan uji regresi logistik untuk menilai kekuatan faktor-faktor tersebut terhadap hubungannya dengan ketidaksesuaian diet ditampilkan dalam Tabel 3.

Tabel 2. Hasil analisis chi-square variabel-variabel yang berhubungan dengan ketidaksesuaian diet

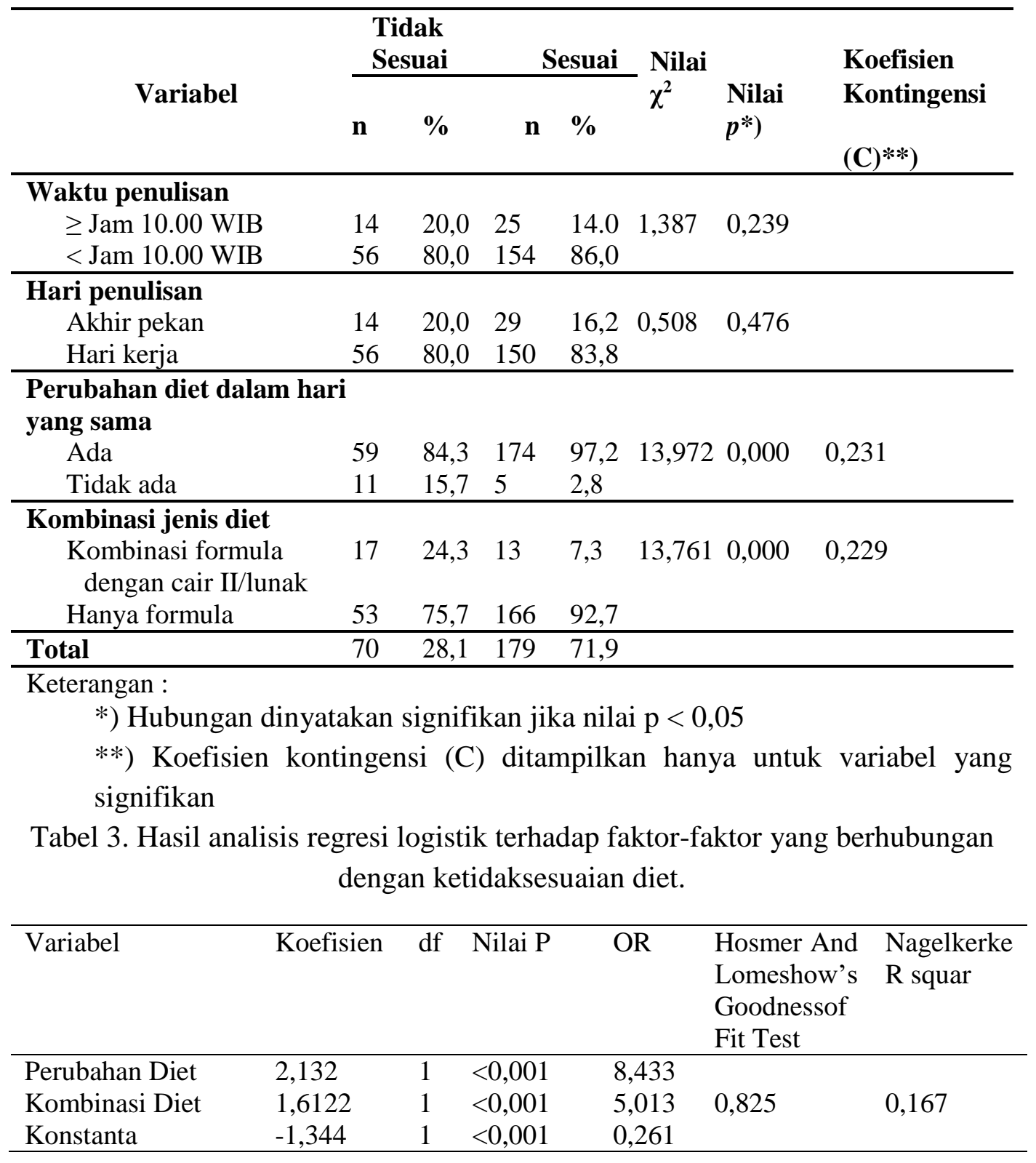




\section{PEMBAHASAN}

Penyusunan preskripsi diet merupakan bagian akhir dari proses pemberian tata laksana gizi pada pasien. Setelah melakukan asesmen gizi dan membuat diagnosis gizi, preskripsi gizi akan dibuat secara tertulis yang selanjutnya akan diterjemahkan ke dalam bentuk menu yang akan diterima pasien. Pemantauan dan evaluasi dilakukan setelah pasien mendapatkan diet berdasarkan preskripsi gizi tersebut untuk menilai toleransi pasien terhadap diet yang diberikan. Preskripsi gizi tersebut pada umumnya mencakup hal-hal seperti jumlah energi dan protein yang akan diterima pasien, jalur pemberian diet, bentuk diet yang akan diberikan, serta frekuensi pemberian diet. Volume air yang akan digunakan untuk membuat formula juga biasanya tertulis dalam preskripsi jika pasien tersebut mendapatkan diet dalam bentuk formula. Penentuan volume air ini juga penting karena pada pasien-pasien yang memerlukan restriksi cairan maka volume air yang diterima pasien akan lebih sedikit dibanding pasien lain yang tidak memerlukan restriksi untuk takaran formula yang sama.

Diet yang dipreskripsikan dengan diet yang diterima pasien dapat mengalami ketidaksesuaian. Ketidaksesuaian diet ini dapat terjadi dalam 2 tahap yang berbeda, yaitu: 1) ketidaksesuaian antara preskripsi yang tertulis di rekam medis dengan menu diet yang diterima pasien; dan 2) menu diet yang diterima pasien sudah sesuai dengan yang dipreskripsikan akan tetapi asupan pasien tidak adekuat karena berbagai hal. Kedua tahap ketidaksesuaian tersebut mempunyai latar belakang yang berbeda sehingga solusi untuk mengatasinya pun memerlukan pendekatan yang berbeda.

Berbagai penelitian telah mengungkapkan adanya ketidaksesuaian antara jumlah energi yang dipreskripsikan dengan yang diterima pasien yang dirawat di ICU, dan ketidaksesuaian ini merupakan penanda prognosistik sebagai prediktor mortalitas pasien ${ }^{4,5,6,17}$.Penelitian-penelitian tersebut sayangnya tidak merinci tahap manakah yang mengalami ketidaksesuaian diet ini memberikanhasil yang cukup baik ${ }^{17-20}$ akan tetapi fokus dari peneliti tersebut adalah padatahap kedua dari ketidaksesuaian diet.

Penelitian yang dilakukan saat ini mencoba untuk menguraikan faktorfaktor yang berhubungan dengan ketidaksesuaian diet tahap pertama, yaitu ketidaksesuaian antara diet yang dipreskripsikan dengan menu diet yang diberikan kepada pasien. Sejauh yang penulis ketahui, penelitian yang berfokus pada ketidaksesuaian antara diet yang dipreskripsikan dengan menu diet yang diberikan kepada pasien belum pernah dilakukan sebelumnya, sehingga penelitian ini dapat disebut sebagai penelitian perintis. Faktor- faktor yang diamati yang diduga berhubungan dengan ketidaksesuaian diet dalam penelitian ini adalah: waktu penulisan preskripsi yaitu sebelum jam 10.00 dan sesudah jam 10.00, hari 
penulisan preskripsi yaitu hari kerja atauakhir pekan, ada atautidaknya perubahan diet dalam hari yang sama, dan jenis diet yang diberikan apakah hanya berbentuk formula saja ataukah dikombinasikan dengan cair II atau lunak.

Data pada tabel 4 menunjukkan bahwa waktu penulisan preskripsi ( $p=$ $0,239)$ dan hari penulisan preskripsi $(p=0,476)$ tidak berhubungan dengan ketidaksesuaian diet. Waktu penulisan preskripsi diduga berhubungan dengan ketidaksesuaian diet karena penyiapan diet memerlukan waktu sampai diet tersebut diterima oleh pasien. Penelitian ini menggunakan nilai cut-off untuk waktu penulisan preskripsi adalah jam 10.00 WIB yang merupakan waktu untuk bagian pantry ruang ICU RSUP Dr Kariadi melakukan order diet ke instalasi gizi sentral. Hasil analisis chi-square memberikan nilai signifikansi sebesar $p=0,239$ yang menunjukkan bahwa hubungan antara waktu penulisan preskripsi dengan ketidaksesuaian diet secara statistik tidak bermakna.

Hari penulisan preskripsi dimasukkan sebagai salah satu faktor yang diamati dengan membandingkan antara hari kerja dengan akhir pekan. Penelitian sebelumnya yang dilakukan oleh Cahill et al mengungkapkan bahwa pada akhir pekan jumlah petugas lebih sedikit daripada pada hari kerja sehingga mempengaruhi tingkat kesesuaian diet. ${ }^{11}$ Hasil analisis bivariat terhadap hari penulisan preskripsi pada penelitian ini menunjukkan bahwa hari penulisan preskripsi secara statistik tidak berhubungan dengan terjadinya ketidaksesuaian $\operatorname{diet}(p=0,476)$

Adanya perubahan diet dalam hari yang sama dan kombinasi jenis diet yang dipreskripsikan mempunyai hubungan yang signifikan dengan ketidaksesuaian diet (keduanya mempunyai nilai $p<0,001$ ). Nilai koefisien kontingensi dari kedua variabel tersebut menunjukkan bahwa hubungan kedua variabel tersebut dengan ketidaksesuaian diet tidak terlalu kuat (perubahan diet dalam hari yang sama: $\mathrm{C}=0,231$; kombinasi jenis diet: $\mathrm{C}=0,229$ ).

Implementasi klinis dari temuan ini adalah dalam membuat preskripsi gizi dianjurkan untuk meminimalkan perubahan diet dalam hari yang sama, dan meminimalkan pemberian diet dalam bentuk kombinasi antara formula enteral dengan cair II atau lunak. Jika keadaan klinis pasien mengharuskan penulisan preskripsi dengan cara tersebut maka pihak-pihak yang terlibat dalam pembuatan menu diet pasien (dokter gizi klinik, ahli gizi, pramu masak, perawat) harus lebih waspada agar tidak terjadi ketidaksesuaian diet.

Kelayakan model regresi dinilai dengan menggunakan Hosmer and Lemeshow's Goodness of Fit Test. Test ini menilai apakah data empiris sesuai dengan model, atau dengan kata lain tidak ada perbedaan antara model dengan data sehingga model dapat dikatakan fit. 
Probabilitas signifikansi Hosmer and Lemeshow's Goodness of Fit Test pada pada uji ini adalah 0,825 (>0,005) sehingga model regresi ini dapat dikatakan fit. Besarnya nilai koefisien determinasi pada model regresi logistik ditunjukkan dengan nilai Nagelkerke R square. Berdasarkan hasil pengujian, nilai Nagelkerke R square pada regresi logistik ini adalah 0,167 atau $16,7 \%$, yang berarti bahwa variabilitas variabel tergantung yang dapat dijelaskan oleh variabel bebas adalah sebesar 16,7 \%, sedangkan sisanya sebesar 83,3\% dijelaskan oleh variabel-variabel lain di luar model penelitian.

Kekuatan utama penelitian ini yaitu bahwa penelitian ini merupakan penelitian pertama yang mengkaji ketidaksesuaian diet dari segi perbedaan antara diet yang dipreskripsikan dengan diet yang diterima pasien. Namun demikian, nilai koefisien determinasi yang ditunjukkan dengan nilai Nagelkerke $\mathrm{R}$ square pada penelitian ini cukup rendah, yaitu hanya $16,7 \%$, yang berarti bahwa variabel-variabel bebas dalam penelitian ini hanya mampu menjelaskan 16,7 \% dari variabilitas ketidaksesuaian diet, sedangkan sisanya yaitu sebesar 83,3\% dijelaskan oleh variabel-variabel lain di luar model penelitian. Hal ini merupakan keterbatasan yang paling menonjol dari penelitian ini. Implikasi dari hal ini adalah perlunya dilakukan upaya-upaya lebih lanjut untuk menggali faktor-faktor lain yang mampu menjelaskan variabilitas ketidaksesuaian diet.

\section{KESIMPULAN}

Ketidaksesuaian diet yang dipreskripsikan dengan diet yang diterima pasien terjadi sebesar 28,1\%dari selurh preskripsi yang dibuat. Ketidaksesuaian ini berhubungan dengan adanya perubahan preskripsi diet dalam hari yang sama dan kombinasi jenis diet yang diberikan pada preskripsi. Waktu penulisan preskripsi dan hari penulisan preskripsi tidak berhubungan dengan terjadinya ketidaksesuaian diet. Faktor yang mempunyai hubungan paling kuat terhadap terjadinyaketidaksesuaian diet yang dipreskripsikan dengan yang diterima pasien di ICU adalah adanya perubahan diet dalam hari yang sama.

\section{SARAN}

Faktor- faktor yang berhubungan dengan ketidaksesuaian diet pada pasien di ICU belum terkolaborasi dengan baik dalam penelitian ini, oleh karena itu perlu dilakukan penelitian lebih lanjut untuk menggali fakto-faktor lain yang berhubungan dengan ketidaksesuaian antara diet yang dipreskripsikan dengan diet yang diterima pasien. Dalam konteks implementasi semua petugas yang terlibat dalam pemberian layanan gizi pada pasien di ICU perlu membangun koordianasi yang kuat untuk mencegah terjadinya ketidaksesuaian antara diet yang dipreskripsikan dengan diet yang diterima pasien. 


\section{DAFTAR PUSTAKA}

1. Mannsdörfer K, Eisele A, Mühleis A, Thorsteinsson R, Riessen R, Bischoff S. PP029-SUN: Prevalence of malnutrition and its relation to complication rates in critically ill patients. Clin Nutr 2014; 33: S29-S30.

2. Powers J, Samaan K. Malnutrition in the ICU patient population. Crit Care Nurs Clin N Am 2014; 26: 227-242.

3. Malone A. Addressing hospital malnutrition-The time is now! JPEN $J$ Parenter Enteral Nutr 2013; 37(4): 439- 440.

4. Jonghe BD, Appere-De-Vechi C, Fournier M, Tran B, Merrer J, Melchior J-C et al. A prospective survey of nutritional support practices in intensive care unit patients: What is prescribed? What is delivered? Crit Care Med 2001; 29: $8-12$.

5. Heyland DK, Dhaliwal R, Wang M, Day AG. The prevalence of iatrogenic underfeeding in the nutritionally "at-risk" critically ill patient: results of an international, multicenter, prospective study. Clin Nutr 2015; 34(4): 659-666.

6. Silva MA, Santos SdGFd, Tomasi CD, Luz Gd, Paula MMdS, Pizzol FD et al. Enteral nutrition discontinuation and outcomes in general critically ill patients. Clinics 2013; 68: 173-178.

7. O’Meara D, Mireles-Cabodevila E, Frame F, Hummell AC, Hammel J, Dweik RA et al. Evaluation of delivery of enteral nutrition in critically ill patients receiving mechanical ventilation. Am J Crit Care 2008; 17(1): 53-61.

8. Sudenis T, Hall K, Cartotto R. Enteral nutrition: What the dietitian prescribes is not what the burn patient gets! J Burn Care Res 2015; 36: 297-305.

9. Kim H, Stotts NA, Froelicher ES, Engler MM, Porter C, Kwak H. Adequacy of early enteral nutrition in adult patients in the intensive care unit. J Clin Nurs 2012; 21(19-20): 2860-2869.

10. Tatucu-Babet OA, Ridley EJ, Tierney AC. The prevalence of underprescription or overprescription of energy needs in critically ill mechanically ventilated adults as determined by indirect calorimetry: A systematic literature review. JPEN JParenter Enteral Nutr 2015; 0148607114567898: 1-14.

11. Cahill NE, MurchL,Cook D, Heyland DK Baarriers to feeding critically ill patients: A multicenter survey of critical care nurses.J crit Care ;2012; 27 p:727-734

12. Ramakrishnan N, Daphnee DK, Ranganathan L, Bhuvaneshwari S. Critical care $24 \times 7$ : But, why is critical nutrition interrupted? Indian J Crit Care Med 2014; 18(3): 144-148.

13. Jones NE, Dhaliwal R, Day AG, Ouellette-Kuntz H, Heyland DK. Factors predicting adherence to the Canadian Clinical Practice Guidelines for nutrition support in mechanically ventilated, critically ill adult patients. J Crit Care 2008; 23(3): 301-307 
14. Jones NE, Suurdt J, Ouellette-Kuntz H, Heyland DK. Implementation of the Canadian Clinical Practice Guidelines for Nutrition Support: a multiple case study of barriers and enablers. Nutr Clin Pract 2007; 22(4): 449-457.

15. Cahill NE, Suurdt J, Ouellette-Kuntz H, Heyland DK. Understanding adherence to guidelines in the intensive care unit: development of a comprehensive framework. JPEN J Parenter Enteral Nutr 2010; 34(6): 616624.

16. Peev MP, Yeh DD, Quraishi SA, Osler P, Chang Y, Gillis E et al. Causes and consequences of interrupted enteral nutrition: A prospective observational study in critically ill surgical patients. JPEN J Parenter Enter Nutr 2015; 39(1): 21-27.

17. Williams TA, Leslie GD, Leen T, Mills L, Dobb GJ. Reducing interruptions to continuous enteral nutrition in the intensive care unit: a comparative study. $J$ Clin Nurs 2013; 22: 2838-2848.

18. Heyland D, Cahill N, Dhaliwal R, Wang M, Day A, Alenzi A et al. Enhanced protein-energy provision via the enteral route in critically ill patients: a single center feasibility trial of the PEP uP protocol. Crit Care 2010; 14(2): 1-12.

19. Heyland DK, Murch L, Cahill N, McCall M, Muscedere J, Stelfox HT et al. Enhanced protein-energy provision via the enteral route feeding protocol in critically ill patients: results of a cluster randomized trial. Crit Care Med 2013; 41(12): 2743-53. 